\title{
Healthcare workers' musculoskeletal disorders, sleep quality, stress, and fatigue during the COVID-19 pandemic
}

\author{
Sağlık çalışanlarının COVID-19 sürecinde, kas iskelet sistemi problemleri, uyku \\ kalitesi, algıladıkları stres ve yorgunluğunun değerlendirilmesi
}

\author{
Nurcan Erdoğan Kurtaran, Mehmet Kurtaran, Samime Şarlı Gündüz, Levent Öztürk
}

Gönderilme tarihi:19.10.2021

Kabul tarihi:31.12.2021

\begin{abstract}
Purpose: The aim of this study is to compare musculoskeletal complaints, sleep quality, stress, and fatigue levels of healthcare workers who took and did not take an active role in the COVID-19 pandemic and to examine the relationship between musculoskeletal complaints and sleep quality, stress and fatigue levels.

Materials and methods: Participants included 194 healthcare workers (Female/Male, 131/63; Mean age, $30.9 \pm 7.6$ years). Participants with an active assignment in COVID-19 related services [COVD group, $n(\%)=124$ (64)] and participants without an active assignment in COVID-19 related services [CONT group, $n(\%)=70$ (36)] were compared. The Extended Nordic Musculoskeletal System Questionnaire, Fatigue Assessment Scale, Perceived Stress Scale, and the Pittsburgh Sleep Quality Index were completed. The relationship between musculoskeletal disorders and fatigue, sleep quality and stress was investigated.

Results: The musculoskeletal disorders of shoulders, upper back, ankle, and hips/thighs regions in the last 4 weeks were more in COVD group compared to CONT group $(p<0.01$ for all). The disorders of pain related to body parts were found to be higher at all measurement points in COVD group. The weekly working hours were $43.9 \pm 14.7$ hours in the COVD group and $34.9 \pm 18.8$ hours in the CONT group $(p=0.001)$. Sleep quality and stress levels were similar whereas fatigue levels were higher in COVD group (COVD, 28.29 \pm 8.49 ; CONT, $24.77 \pm 7.02 ; p=0.002$ ). A significant relationship was found between musculoskeletal pain in the last 4 weeks and the fatigue, sleep quality, and stress.

Conclusions: Healthcare workers who took an active assignment during the COVID-19 pandemic period had more musculoskeletal disorders, fatigue levels and working hours compared to those without an active assignment.
\end{abstract}

Key words: COVID-19, healthcare worker, musculoskeletal disorders, sleep quality, stress.

Erdogan Kurtaran N, Kurtaran M, Sarli Gunduz S, Ozturk L. Healthcare workers' musculoskeletal disorders, sleep quality, stress, and fatigue during the COVID-19 pandemic. Pam Med J 2022;15:441-450.

Öz

Amaç: Bu çalışmanın amacı, COVID-19 pandemisinde aktif rol alan ve almayan sağlık çalışanlarının kas-iskelet şikayetleri, uyku kalitesi, stres ve yorgunluk düzeylerini karşılaştırmak ve kas iskelet sistemi şikayetleri ile uyku kalitesi, stress ve yorgunluk seviyeleri arasındaki ilişkiyi incelemektir.

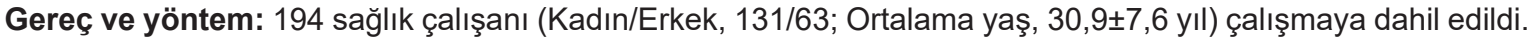
Pandemilerde aktif görevi olan katılımcılar [COVD grubu; n (\%)=124 (64)] ve aktif görev almayanlar [CONT grubu; n (\%)=70 (36)] karşılaştırıldı. Genişletilmiş Nordik Kas-İskelet Sistemi Anketi, Yorgunluk Değerlendirme Ölçeği, Algılanan Stres Ölçeği ve Pittsburgh Uyku Kalitesi İndeksi kullanıldı. Kas-iskelet sistemi rahatsızlıkları ile yorgunluk, uyku kalitesi ve stres arasındaki ilişki araştırıldı.

Bulgular: Son 4 hafta içinde omuz, sırt, ayak bileği ve kalça/uyluk bölgelerindeki kas-iskelet sistemi rahatsızlıkları CONT grubuna göre COVD grubunda daha fazlaydı (tümü için $p<0,01$ ). COVD grubunda vücut bölgelerine bağıı ağrı bozuklukları tüm ölçüm noktalarında daha yüksek bulundu. Haftalık çalışma saati COVD grubunda $43,9 \pm 14,7$ saat, CONT grubunda ise $34,9 \pm 18,8$ saatti $(p=0,001)$. COVD grubunda uyku kalitesi ve stres düzeyleri benzerken, yorgunluk düzeyleri daha yüksekti (COVD, 28,29 $\pm 8,49$; CONT, 24,77 $\pm 7,02 ; p=0,002$ ). Son 4 haftadaki kas-iskelet ağrısı ile yorgunluk, uyku kalitesi ve stres arasında ilişki bulundu.

Sonuç: COVID-19 pandemisinde aktif görev alan sağlık çalışanlarında aktif görev almayanlara göre daha uzun çalışma saati, daha fazla kas-iskelet sistemi rahatsızlığı ve daha yüksek yorgunluk düzeyi bulundu.

Anahtar kelimeler: COVID-19, sağlık çalışanı, kas-iskelet sistemi rahatsızlıkları, uyku kalitesi, stres.

Nurcan Erdoğan Kurtaran, Lecturer, Department of Electroneurophysiology, Trakya University Vocational School of Health Services, Edirne, Turkey, e-mail: nurcanerdogan@trakya.edu.tr (https://orcid.org/0000-0002-8076-2050) (Corresponding Author)

Mehmet Kurtaran, Lecturer, Department of Orthopedic Prosthetics and Orthotics, Trakya University Vocational School of Health Services, Edirne, Turkey / Department of Physiotherapy and Rehabilitation, Istanbul University-Cerrahpasa Graduate Education Institute, Istanbul, Turkey, e-mail: mehmetkurtaran@trakya.edu.tr (https://orcid.org/0000-0001-8257-4400)

Samime Şarlı Gündüz, Lecturer, Department of Anesthesia, Trakya University Vocational School of Health Services, Edirne, Turkey, e-mail: samimegunduz@trakya.edu.tr (https://orcid.org/0000-0001-7414-8874)

Levent Öztürk, Prof. Department of Physiology, Trakya University Faculty of Medicine, Edirne, Turkey, e-mail: leventozturk@trakya.edu.tr (https://orcid.org/0000-0002-0182-3960) 
Erdoğan Kurtaran N, Kurtaran M, Şarlı Gündüz S, Öztürk L. Sağlık çalışanlarının COVID-19 sürecinde, kas iskelet sistemi problemleri, uyku kalitesi, algıladıkları stres ve yorgunluğunun değerlendirilmesi. Pam Tıp Derg 2022;15:441-450.

\section{Introduction}

COVID-19 is a disease that created a pandemic with more than 240 million cases worldwide in the last year, caused approximately 4.8 million deaths and changed the whole dynamics of daily life [1]. During the pandemic, all institutions providing health services were alarmed, and healthcare workers were mainly assigned to fight against this disease outside of their area of expertise [2]. These conditions suggest that healthcare workers may have sleep problems, anxiety, depression, and stress symptoms due to the risk they face. Furthermore, it was observed that the anxiety level of healthcare workers who worked especially in pandemic departments increased when the difficulty of staying away from the family and working with clothes such as coveralls worn to prevent transmission from patients was added to long working hours [3, 4]. It was demonstrated that healthcare workers who took an active assignment in the COVID19-related departments had more disorders of anxiety and insomnia compared to healthcare workers without an active assignment [5]. In a study in which Chinese healthcare workers in the COVID-19 pandemic participated, the prevalence of those with poor sleep quality was found between $34-36 \%$. Furthermore, it was determined that healthcare workers working in the isolation departments of patients with COVID-19 were concerned about being infected [6]. It was revealed that healthcare workers in Italy had health problems such as stressrelated symptoms, anxiety, and insomnia during COVID-19 pandemic [7]. In a multinational and multicenter study, a significant relationship was found between negative psychological outcomes among healthcare workers during the current COVID-19 pandemic and the existing physical symptoms. Concerning physical symptoms, headache, sore throat, lethargy, and insomnia were investigated [8]. In a study in which the musculoskeletal disorders of nurses in Iran were investigated shortly before COVID-19 pandemic, it was demonstrated that upper back, knees, and hips/thighs pain was more compared to other parts. It is argued that upper back pain is the most common $(88.3 \%)$ musculoskeletal disease. Furthermore, it was reported that the extent and location of pain might be associated with standing posture, working habits, and other demographic characteristics, along with other symptoms [9]. During the COVID-19 pandemic, the necessity of working with protective clothing, standing for a long time, and coping with the number of patients above the burden that the health system can handle indicate that physical symptoms will increase among workers. Working for a long time and in non-ergonomic environments increases musculoskeletal disorders.

Healthcare workers indicate that they have serious physical and mental fatigue in addition to the anxiety of being infected, are in a difficult situation due to burden of triage decisions, and experience more psychological fatigue when the grief of losing patients and colleagues is added to the current situation [10]. Studies conducted to examine the general conditions of healthcare workers during the COVID-19 pandemic focused on measuring psychological influences such as anxiety, stress, and depression. As a result of our reviews, we found a limited number of studies examining the physical effects of the pandemic on healthcare workers. In this study, we aimed to evaluate both the physical and psychological effects on healthcare workers during the COVID-19 pandemic.

\section{Materials and methods}

Permission for the study was obtained from the Ministry of Health and the study protocol was approved by Trakya University Faculty of Medicine Scientific Research Ethics Committee. The study was conducted in accordance with the Declaration of Helsinki. All participants provided written informed consent.

\section{Participants and procedure}

The study group was formed with the participation of 194 [131 (67.5\%) females, $63(32.5 \%)$ males] healthcare workers aged between 20-53 years (Mean $\pm S D=22.1 \pm 4.1$ years) from 26 different provinces of Turkey. The participants were divided into two groups as those who took an active assignment in the 
COVID-19-related departments [COVD group, n $(\%)=124(64)$ ] and those who did not take an active assignment [CONT group, $\mathrm{n}(\%)=70$ (36)]. The inclusion criteria were determined as having been working actively as a healthcare worker for at least one year and knowing Turkish enough to understand and respond to the scales. The study was conducted with the participants' online responses to the evaluation form prepared in the electronic environment. We developed an online survey (GoogleForms). We used snowball non-probability sampling for recruitment of participants. The questionnaire link was first sent to the Whatsapp groups that the authors are members, and then respondents were encouraged to forward the link to other groups, friends and colleagues.

\section{Measures}

\section{Sociodemographic and other characteristics form}

It consisted of 10 questions including the characteristics of the participants such as age, gender, height, weight, working hours before and during the pandemic, profession, diagnosis with COVID-19, and taking an active assignment in the COVID-19-related departments.

\section{Extended Nordic musculoskeletal system questionnaire (NMQ-E)}

The NMQ-E is a scale that can be used for musculoskeletal pain and related conditions in studies conducted in working and/or general communities. The NMQ-E examines the presence of pain, ache, or discomfort in nine body parts in the last 12 months, in the last 4 weeks, and on the day of the evaluation and evaluates pain with a score of 0-10 (0: no pain, 10: unbearable pain). Its Turkish validity and reliability studies were performed by Kahraman et al. [11].

\section{Pittsburgh sleep quality index (PSQI)}

The PSQI is a sleep questionnaire that helps to evaluate sleep quality, the amount of sleep, the presence and severity of sleep disturbances among individuals for the last month. Its Turkish validity and reliability studies were performed by Agargün et al. [12]. This scale has 19 items in seven sub-scores. The total PSQI score is obtained by adding seven sub-scores, and the total score is between $0-21$. A high score indicates that the person's sleep quality has deteriorated. The total PSQI score distinguishes good sleepers (Total PSQI score $\leq 5$ ) from poor sleepers (PSQI>5).

\section{Perceived stress scale (PSS)}

The PSS was designed to measure the degree to which individuals perceive their lives as stressful. It consists of a total of 14 items. Its Turkish validity and reliability studies were performed by Eskin et al. [13]. Participants evaluate each item based on a 5-point Likerttype scale ranging from "Never (0)" to "Very often (4)." Seven items with positive statements are scored in reverse. The PSS scores range from 0 to 56 , and a high score indicates the excessive perception of stress.

\section{Fatigue assessment scale (FAS)}

The FAS assesses fatigue by examining physical and psychological fatigue. The scale consists of 10 questions. The total score varies between 10-50, and a high score indicates an increase in the fatigue level of the person. While a FAS score of less than 22 is considered as no fatigue, a score between 22-34 is considered as fatigue, and a score of 35 and above is considered as extreme fatigue [14].

\section{Statistical analysis}

Mean, percentage distribution, and standard deviation values were calculated using descriptive statistical methods. The compatibility of the data to normal distribution was tested by the Kolmogorov-Smirnov normality test. Student's t-test was used to compare musculoskeletal disorders, sleep quality, stress, and fatigue levels of the COVD and CONT groups. The relationship between musculoskeletal disorders and sleep quality, stress, and fatigue level was examined by the Pearson correlation test. The significance level was adjusted to $p<0.05$.

\section{Results}

Demographic, anthropometric, and other characteristics of the study groups are presented in Table 1. The COVD and CONT groups were observed to be similar in terms of gender distribution and mean age. While the mean weekly working hours before the pandemic were similar in both groups, it was observed that the COVD group worked more hours than the CONT 
group during the pandemic $(43.9 \pm 14.6$ hours/ week and 34.9 \pm 18.8 hours/week; $p=0.001$, respectively). The number of individuals who or whose family member had the diagnosis of COVID-19 was $33(26.6 \%)$ in the COVD group and $15(21.4 \%)$ in the CONT group $(p=0.42)$.
The comparison of musculoskeletal disorders between the groups in two different time periods according to body parts is presented in Table 2. In general, higher numbers of individuals reported pain disorders in the COVD group than in the CONT group. The presence of pain in the last 4 weeks was higher in the COVD group

Table 1. Demographic, anthropometric, and other characteristics of the study groups

\begin{tabular}{llll}
\hline Variables $^{\dagger}$ & $\begin{array}{l}\text { COVD } \\
(\mathrm{N}=124)\end{array}$ & $\begin{array}{l}\text { CONT } \\
(\mathrm{N}=70)\end{array}$ & $p^{\ddagger}$ \\
\hline $\begin{array}{l}\text { Demographic } \\
\quad \text { Gender, F/M }\end{array}$ & $86 / 38$ & $45 / 25$ & 0.469 \\
$\quad$ Age, year & $30.8 \pm 7.5$ & $31.0 \pm 8.1$ & 0.864 \\
Anthropometric & & \\
$\quad$ BMI, kg/m² & $23.4 \pm 4.0$ & $24.7 \pm 3.7$ & 0.028 \\
Weekly working time & & & \\
$\quad$ Before the pandemic, hour & $45.2 \pm 8.1$ & $44.2 \pm 6.5$ & 0.405 \\
$\quad$ Pandemic period, hour & $43.9 \pm 14.7$ & $34.9 \pm 18.8$ & 0.001 \\
Profession group & & & \\
$\quad$ Doctor, $\mathrm{n}(\%)$ & $17(13.7)$ & $4(5.7)$ & 0.085 \\
$\quad$ Nurse, $\mathrm{n}(\%)$ & $35(28.3)$ & $16(22.9)$ & 0.415 \\
$\quad$ Dentist, $\mathrm{n}(\%)$ & $27(21.8)$ & $2(2.9)$ & 0.000 \\
$\quad$ Physiotherapist, $\mathrm{n}(\%)$ & $5(4.0)$ & $17(24.3)$ & 0.000 \\
$\quad$ Midwife, $\mathrm{n}(\%)$ & $3(2.4)$ & $4(5.7)$ & 0.237 \\
Pharmacist, $\mathrm{n}(\%)$ & $1(0.8)$ & $4(5.7)$ & 0.038 \\
Health technician, $\mathrm{n}(\%)$ & $36(29.0)$ & $23(32.8)$ & 0.578 \\
Diagnosed with COVID-19, $\mathrm{n}(\%)$ & $33(26.6)$ & $15(21.4)$ & 0.422 \\
\hline
\end{tabular}

†The $p$ values of gender distribution and profession groups are the results of the Chi-Square test, and the $p$ values of the other parameters are the Student's t-test results

‡Data are expressed as mean \pm standard deviation or percentage

COVD: Participants with an active assignment in COVID-19 related services

CONT: Participants without an active assignment in COVID-19 related services

F: Female, M: Male, BMI: Body mass index

Table 2. Musculoskeletal disorders of the study groups

\begin{tabular}{lllllll}
\hline & Last 12 months & & \multicolumn{3}{c}{ Last 4 weeks } \\
& $\begin{array}{l}\text { COVD } \\
\text { N (\%) }\end{array}$ & $\begin{array}{l}\text { CONT } \\
\text { N (\%) }\end{array}$ & $\boldsymbol{p}^{+}$ & $\begin{array}{l}\text { COVD } \\
\text { N }(\%)\end{array}$ & CONT & $\boldsymbol{p}^{+}$ \\
\hline Neck & $95(77)$ & $48(69)$ & 0.222 & $98(79)$ & $46(66)$ & $\mathbf{0 . 0 4 2}$ \\
Shoulders & $95(77)$ & $41(59)$ & $\mathbf{0 . 0 0 8}$ & $94(76)$ & $38(54)$ & $\mathbf{0 . 0 0 2}$ \\
Elbow & $32(26)$ & $16(23)$ & 0.648 & $41(33)$ & $15(21)$ & 0.086 \\
Wrists/hands & $61(49)$ & $22(31)$ & $\mathbf{0 . 0 1 6}$ & $61(49)$ & $21(30)$ & $\mathbf{0 . 0 0 9}$ \\
Upper Back & $105(85)$ & $52(74)$ & 0.077 & $105(85)$ & $46(66)$ & $\mathbf{0 . 0 0 2}$ \\
Lower Back & $100(81)$ & $47(67)$ & $\mathbf{0 . 0 3 5}$ & $101(81)$ & $42(60)$ & $\mathbf{0 . 0 0 1}$ \\
Hips/thighs & $69(56)$ & $24(34)$ & $\mathbf{0 . 0 0 4}$ & $70(56)$ & $22(31)$ & $\mathbf{0 . 0 0 1}$ \\
Knees & $69(56)$ & $30(43)$ & 0.087 & $67(54)$ & $31(44)$ & 0.192 \\
Ankles/feet & $76(61)$ & $30(43)$ & $\mathbf{0 . 0 1 3}$ & $78(63)$ & $29(41)$ & $\mathbf{0 . 0 0 4}$ \\
\hline
\end{tabular}

${ }^{\dagger}$ Chi-Square test

COVD: Participants with an active assignment in COVID-19 related services

CONT: Participants without an active assignment in COVID-19 related services 
than in the CONT group compared to the last 12 months. When the last 12-month period was examined, it was observed that pain disorders in the shoulders, wrists/hands, lower back, hips/ thighs, and feet were significantly higher in the COVD group compared to the CONT group and that the neck and upper back regions were also added to these anatomical regions in the last 4 weeks.
The comparison of the musculoskeletal pain scores of the groups according to the regions is presented in Figure 1. It was observed that the disorders of pain related to body parts were generally higher at all measurement points in the COVD group compared to the CONT group. When the day the questionnaire was answered was compared with the last one-month period, the reports of pain tended to decrease in both groups.
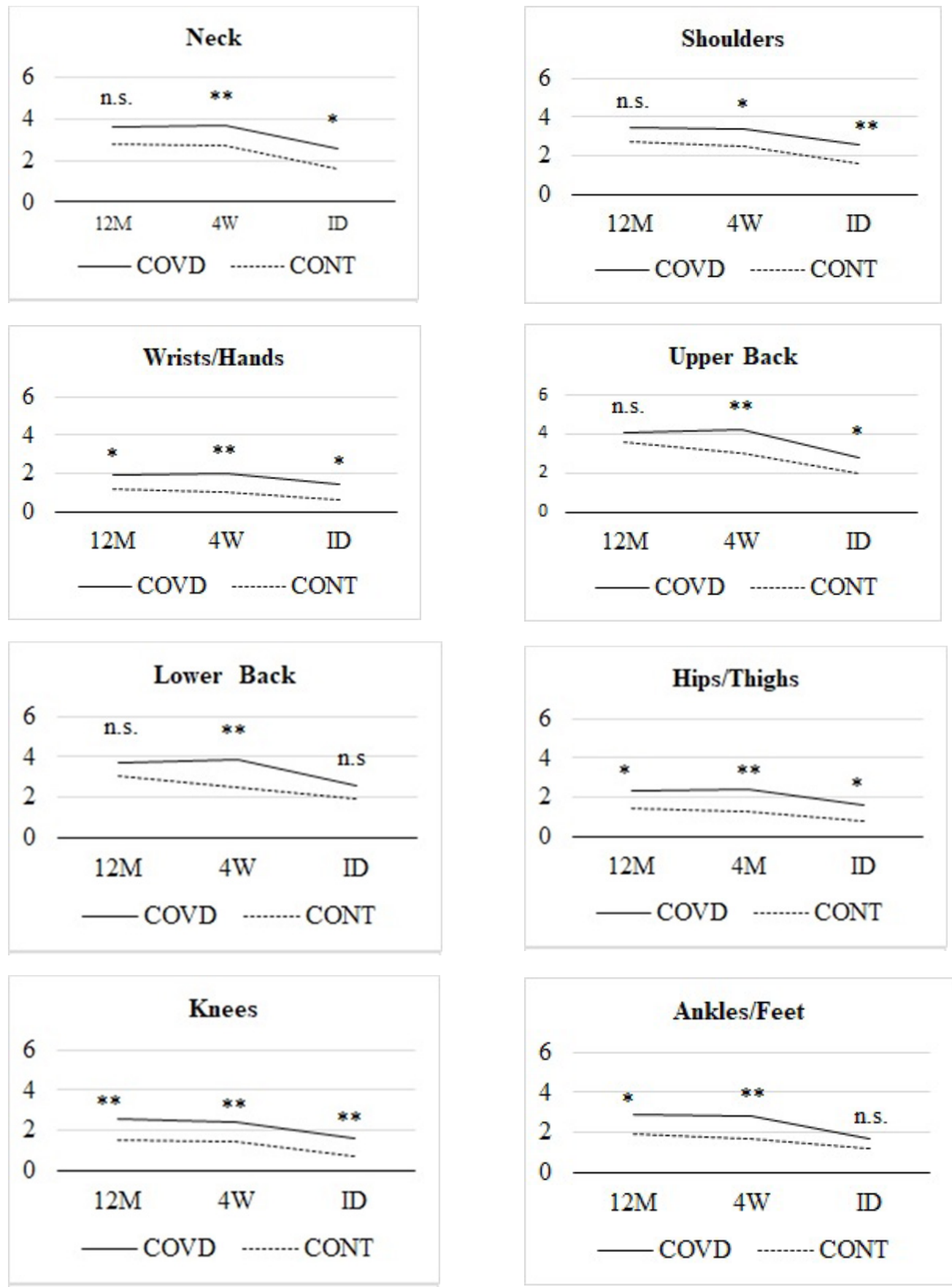

Figure 1. Musculoskeletal pain scores in the groups with an assignment in the COVID-19-related departments during the pandemic (COVD) and without an assignment (CONT)

The $p$-values in the graphs were obtained from Student's t-test. 12M: The last 12-month,

4M: The last 4-week, ID: The interview day. ${ }^{* * *} p<0.001,{ }^{* *} p<0.01,{ }^{*} p<0.05$, n.s. $=$ nonsignificant 
The comparison of the participants PSS, $P S Q I$, and FAS scores between the groups is presented in Figure 2A. It was observed that the FAS scores were higher in the COVD group compared to the CONT group. While the PSS scores were similar between genders in the CONT group, they were found to be higher in the female gender in the COVD group (Figure $2 B$ ). The FAS scores were found to be higher in the female gender compared to the male gender in the COVD and CONT groups (Figure 2C).
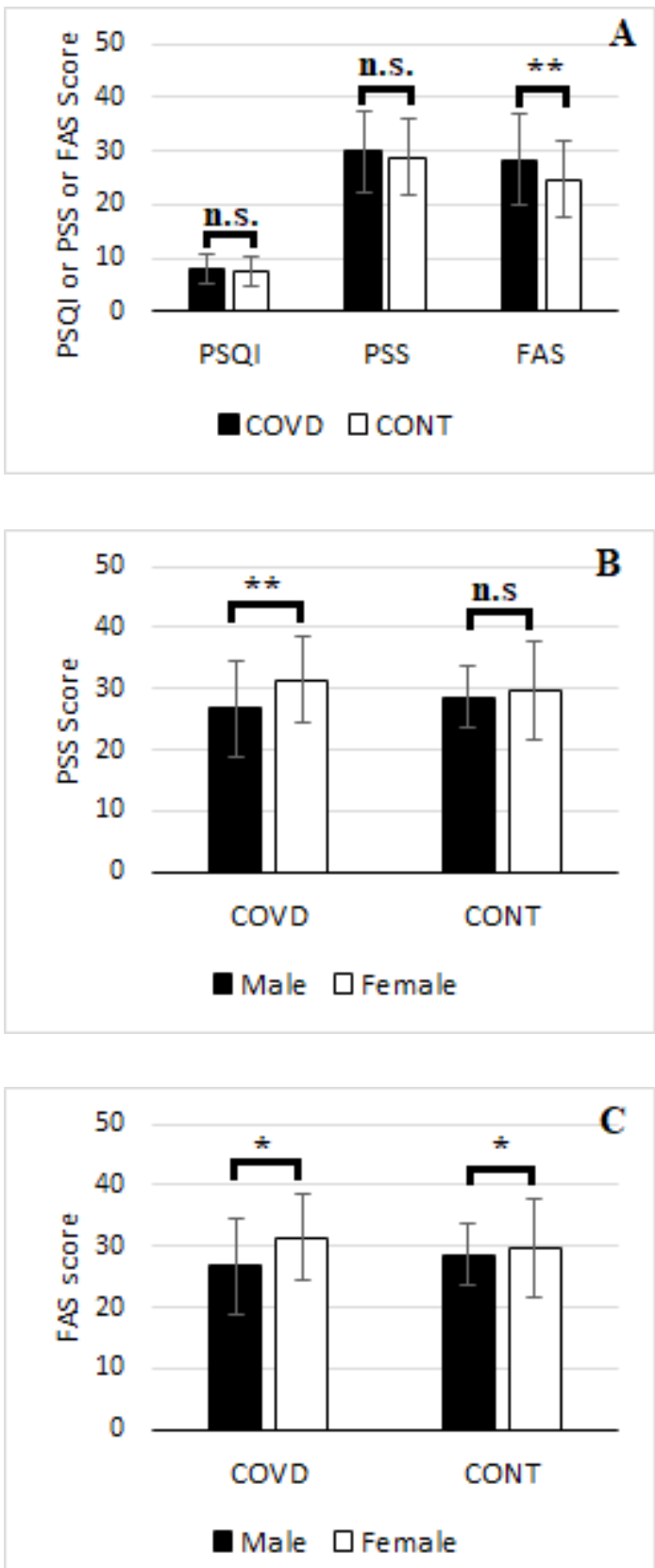

Figure 2. In the groups with an assignment in the COVID-19-related departments during the pandemic (COVD) and without an assignment (CONT)

A: Comparison of the PSQI, PSS, and FAS results,

B: Perceived stress levels by gender,

C: Fatigue levels by gender. ${ }^{* *} p<0.001,{ }^{* *} p<0.01,{ }^{*} p<0.05$, n.s. $=$ nonsignificant 


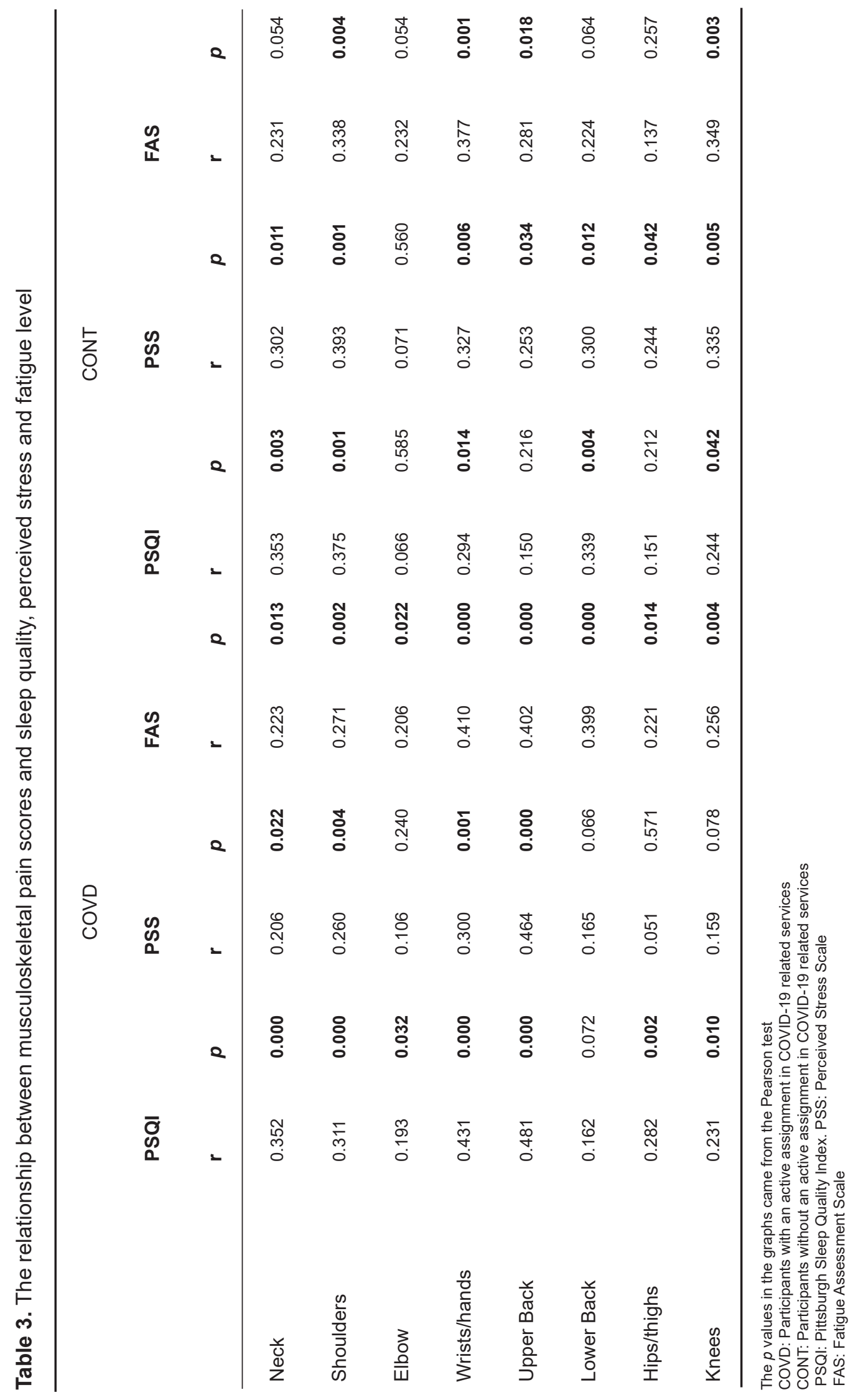


musculoskeletal disorders were reported in the last 4 weeks. The PSS scores were found to be associated with other regions except for the wrists/hands region, among the regions with musculoskeletal disorders in the last 4 weeks.

\section{Discussion}

In our study, it was found that healthcare workers who took an active assignment in the diagnosis and treatment of COVID-19 patients (COVD group) had more fatigue and musculoskeletal disorders compared to healthcare workers in the departments that were not directly related to COVID-19 (CONT group). Since sleep quality and stress levels were similar in both groups, it was considered that the difference in fatigue and musculoskeletal disorders was not associated with sleep quality or stress.

The higher level of fatigue in the COVD group may have some reasons such as working hours, sleep quality, or changes in stress level. While the weekly working hours did not change in the COVD group during the pandemic period, it was found that they decreased by approximately $21 \%$ in the CONT group, which was considered to be due to the fact that the pandemic departments primarily provided health services in the fight against the COVID-19 pandemic and that health services in other departments that did not provide pandemic services were restricted to reduce the potential risk of transmission from hospitals. Indeed, in a study in which 254 healthcare workers during the COVID-19 pandemic period participated, it was reported that $83.5 \%$ of the participants worked 40 hours or more per week [15]. In another study, it was determined that $55.8 \%$ of healthcare workers worked more hours than that specified in their contracts during the pandemic period [16]. It has long been known that the level of fatigue is affected by sleep characteristics. The duration and quality of sleep the night before may determine the level of fatigue on the next day [17]. However, in this study, we did not find a difference between the subjective sleep quality scores of the COVD and CONT groups. In another study conducted on nurses during the pandemic in China, it was observed that participants with high levels of anxiety, depression, and stress obtained higher scores from physical and mental fatigue [18]. In the COVD group, the stress level was slightly higher; however, the difference did not reach statistical significance. On the other wrists/ hands, stress was higher in females compared to males in the COVD group.

It is known that musculoskeletal disorders are common among healthcare workers. In our study, we found that the musculoskeletal disorders of all body parts in the last 12 months and last 4 weeks evaluated by the NMQ-E were higher in the COVD group compared to the CONT group [15]. While musculoskeletal disorders of the neck and upper back regions were similar in the last 12 months in the COVD and CONT groups, the disorders in the last 4 weeks were higher in the COVD group compared to the CONT group, the reason for which may be changes in the workload, working hours, sleep quality, and stress levels in the fight against COVID-19. In a study conducted on healthcare workers in China, it was demonstrated that workload and psychological factors were associated with musculoskeletal disorders [19]. While the concept of workload includes excessive weekly working hours, reduced break times during the working day, and standing for a long time, psychological factors refer to mental fatigue and stress. Excessive weekly working hours and reduced break times during the working day may significantly increase musculoskeletal disorders because longer working hours may lead to longer standing in a bad position and exposure of joints to more pressure. In our study, factors such as longer working hours, reduced rest times during work due to a high number of patients, and higher mental fatigue in the COVD group were observed to be associated with the increase in musculoskeletal disorders. Furthermore, working with protective equipment in the fight against COVID-19 may have increased the spine pain of workers since it restricts body movements and adds weight. The pain level of the COVD group was higher in all regions in three time periods (last 12 months, last 4 weeks, last day) compared to the CONT group, and the pain level on the last day was lower in both groups compared to other time periods, which may be because they filled out the form before the end of the day, did not work on the last day due to the shift, and examined a shorter period of time compared to other time periods. In the comparison of the regional pain level between the groups, it was determined that the COVD group had more severe pain in the 
wrists/hands, hips/thighs, knees, and ankles/ feet regions in the last 12 months and all body parts in the last 4 weeks compared to the CONT group. Considering the time period during which our study was conducted, it was observed that the evaluation results of healthcare workers for the last 4 weeks covered a period of the intense fight against the pandemic, and the evaluation results for the last 12 months covered the prepandemic period. Therefore, the high level of musculoskeletal disorders and pain level reported for the last 4 weeks in the COVD group may be related to the working conditions caused by the fight against COVID-19.

In our study, when the results of the correlation analysis between musculoskeletal disorders and sleep quality, stress and fatigue for the last 4 weeks in the COVD and CONT groups were examined, the PSQI and FAS scores were associated with pain scores of almost all regions of the musculoskeletal system in the COVD group. However, this relationship was found for certain regions in the CONT group (See Table 3 ), which can be explained by the increase in the fatigue level of the COVD group due to longer working hours compared to the CONT group. The increase in the fatigue level may be a reason for the increase in musculoskeletal disorders. In the study conducted by Younan et al. [20] on 2852 nurses, it was observed that the probability of developing musculoskeletal disorders increased as the level of fatigue increased. The most common musculoskeletal disorders is upper back pain (83.7\%). In our study, there was a relationship between upper back pain and fatigue level in both the COVD and CONT groups. Furthermore, sleep disorders and musculoskeletal disorders were common among healthcare workers. In the study conducted by Zhang et al. [21] with 397 nurses, it was observed that there was a high prevalence of musculoskeletal disorders and sleep problems among nurses. In a largescale study conducted by Mork et al. [22] it was demonstrated that there was a positive and dose-dependent relationship between the frequency of sleep problems and the risk of chronic pain in the lower back, neck, and shoulders. In our study, the PSQI scores were not different between the COVD and CONT groups during the pandemic period. However, there was a correlation between pain scores of the neck, shoulders, upper back, and ankles/ feet regions and the PSQI scores in both groups. Furthermore, pain scores in other regions in the COVD group were also associated with the PSQI scores.

\section{Limitations}

Our study has some limitations. The first limitation may be the relatively small number of participants. Increasing the number of participants could increase the representation power. The second limitation is that the questionnaires were applied through the online method rather than face-to-face interviews. However, this approach was relatively inevitable due to pandemic conditions. The final limitation is related to the cross-sectional nature of this study. There is a need for longitudinal studies to observe long-term results.

As a result; healthcare workers who took an active assignment during the COVID-19 pandemic had more musculoskeletal disorders, fatigue levels, and working hours compared to those without an active assignment. It was revealed that healthcare workers working in both pandemic departments and other health services mostly had musculoskeletal disorders in the spine, increased fatigue, decreased sleep quality, and increased stress levels during the COVID-19 pandemic period. Furthermore, it was found that there was a relationship between fatigue, sleep quality and stress, and it was observed that workers working in pandemic departments had more fatigue disorders

Conflict of interest: No conflict of interest was declared by the authors.

\section{References}

1. WHO. WHO coronavirus disease (COVID-19 dashboard). Available at: https://covid19.who.int/. Accessed October 18, 2021

2. Resmi Gazete. T.C. The Ministry of Health. Regulation to change certain issues of the regulation on specialized education in medicine and dentistry. The Official Gazette of The Republic of Turkey. Available at: https:// www.resmigazete.gov.tr/eskiler/2020/11/20201126-10. $\mathrm{htm}$. Accessed Novomber 26, 2020

3. Zhou $\mathrm{Y}$, Yang $\mathrm{Y}$, Shi $\mathrm{T}$, et al. Prevalence and demographic correlates of poor sleep quality among frontline health professionals in liaoning province, China during the COVID-19 outbreak. Front Psychiatry 2020;11:520. https://doi.org/10.3389/fpsyt.2020.00520

4. Zhu J, Sun L, Zhang L, et al. Prevalence and influencing factors of anxiety and depression symptoms in the firstline medical staff fighting against COVID-19 in Gansu. Front Psychiatry 2020;11:386. https://doi.org/10.3389/ fpsyt.2020.00386 
5. Lai J, Ma S, Wang $Y$, et al. Factors associated with mental health outcomes among health care workers exposed to coronavirus disease 2019. JAMA Netw Open 2020;3:e203976. https://doi.org/10.1001/ jamanetworkopen.2020.3976

6. Zhang SX, Liu J, Afshar Jahanshahi A, et al. Corrigendum to "At the height of the storm: healthcare staff's health conditions and job satisfaction and their associated predictors during the epidemic peak of COVID-19". Brain Behav Immun 2021;92:245-246. https://doi.org/10.1016/j.bbi.2020.11.021

7. Rossi R, Socci V, Pacitti F, et al. Mental health outcomes among frontline and second-line health care workers during the Coronavirus Disease 2019 (COVID-19) pandemic in Italy. JAMA Netw Open 2020;3:e2010185. https://doi.org/10.1001/jamanetworkopen.2020.10185

8. Chew NWS, Lee GKH, Tan BYQ, et al. A multinational, multicentre study on the psychological outcomes and associated physical symptoms amongst healthcare workers during COVID-19 outbreak. Brain Behav Immun 2020;88:559-565. https://doi.org/10.1016/j. bbi.2020.04.049

9. Heidari M, Borujeni MG, Rezaei P, Kabirian Abyaneh $S$. Work-related musculoskeletal disorders and their associated factors in nurses: a cross-sectional study in Iran. Malays J Med Sci 2019;26:122-130. https://doi. org/10.21315/mjms2019.26.2.13

10. The Lancet. COVID-19: protecting health-care workers. Lancet 2020;395:922. https://doi.org/10.1016/S01406736(20)30644-9

11. Kahraman T, Genç A, Göz E. The Nordic Musculoskeletal Questionnaire: cross-cultural adaptation into Turkish assessing its psychometric properties. Disabil Rehabil 2016;38:2153-2160. https://doi.org/10.3109/09638288.2015.1114034

12. Ağargün $M Y, K a r a ~ H$, Anlar Ö. The validity and reliability of the Pittsburgh Sleep Quality Index. Turk Psikiyatri Derg 1996;7:107-115.

13. Eskin M, Harlak H, Demirkiran F, Dereboy Ç. The adaptation of the perceived stress scale into Turkish: a reliability and validity analysis. New Symp J 2013;51:132-140. Available at: http://yenisymposium. com/en/Detail.aspx?MkID=435. Accessed October 22, 2021

14. Marcellis RG, Lenssen A, Elfferich $M$, et al. Exercise capacity, muscle strength and fatigue in sarcoidosis. Eur Respir J 2011;38:628-634. https://doi. org/10.1183/09031936.00117710

15. Kafle K, Shrestha DB, Baniya A, et al. Psychological distress among health service providers during COVID-19 pandemic in Nepal. Plos One 2021;16:e0246784. https://doi.org/10.1371/journal. pone. 0246784
16. Kok N, Van Gurp J, Teerenstra S, et al. Coronavirus Disease 2019 Immediately Increases burnout symptoms in ICU professionals: a longitudinal cohort study. Crit Care Med 2021;49:419-427. https://doi. org/10.1097/CCM.0000000000004865

17. Cho H, Brzozowski S, Knudsen ÉNA, Steege LM. Changes in fatigue levels and sleep measures of hospital nurses during two 12-hour work shifts. J Nurs Adm 2021;51:128-134. https://doi.org/10.1097/ NNA.0000000000000983

18. Zhan YX, Zhao SY, Yuan J, et al. Prevalence and influencing factors on fatigue of first-line nurses combating with COVID-19 in China: a descriptive cross-sectional study. Curr Med Sci 2020;40:625-635. https://doi.org/10.1007/s11596-020-2226-9

19. Dong $H$, Zhang Q, Liu G, Shao T, Xu Y. Prevalence and associated factors of musculoskeletal disorders among Chinese healthcare professionals working in tertiary hospitals: a cross-sectional study. BMC Musculoskelet Disord 2019;20:175. https://doi.org/10.1186/s12891019-2557-5

20. Younan L, Clinton M, Fares S, Jardali FE, Samaha H. The relationship between work-related musculoskeletal disorders, chronic occupational fatigue, and work organization: a multi-hospital cross-sectional study. J Adv Nurs 2019;75:1667-1677. https://doi.org/10.1111/ jan.13952

21. Zhang Y, Duffy JF, De Castillero ER, Wang K. Chronotype, sleep characteristics, and musculoskeletal disorders among hospital nurses. Workplace Health Saf 2018;66:8-15. https://doi. org/10.1177/2165079917704671

22. Mork PJ, Vik KL, Moe B, Lier R, Bardal EM, Nilsen TIL. Sleep problems, exercise and obesity and risk of chronic musculoskeletal pain: the Norwegian HUNT study. Eur J Public Health 2014;24:924-929. https://doi. org/10.1093/eurpub/ckt198

Ethics committee approval: Approval for the study was obtained from the Ministry of Health and Trakya University Faculty of Medicine Scientific Research Ethics Committee (date: 22/05/2020 and decision number: 09/34).

\section{Contributions of the authors to the article}

N.E.K., M.K. and L.O. conceived the study design. N.E.K. and S.S.G. was involved in data collection. M.K. performed the statistical analysis. N.E.K., S.S.G. and M.K. interpreted data and prepared the manuscript draft. L.O. and S.S.G. critically reviewed the final version of the manuscript. All authors approved the final version of the manuscript. 